\title{
The Contribution of Matrix Metalloproteinase-1 Genotypes to Hepatocellular Carcinoma Susceptibility in Taiwan
}

\author{
YI-LIANG LAI ${ }^{1 *}$, CHI-LI GONG ${ }^{2 *}$, CHUN-KAI FU ${ }^{1,3^{*}}$, TE-CHENG YUEH ${ }^{1,3}$, CHIA-WEN TSAI $^{4}$, \\ WEN-SHIN CHANG ${ }^{4}$, CHIEH-LUN HSIAO ${ }^{4}$, SHIOU-TING YEN ${ }^{4}$, HSIN-TING LI ${ }^{4}$, \\ LONG-BIN JENG ${ }^{4}$, SHOU-CHENG WANG ${ }^{1,5^{*}}$ and DA-TIAN BAU $3,4,6^{*}$ \\ ${ }^{1}$ Taichung Armed Forces General Hospital, Taichung, Taiwan, R.O.C.; \\ ${ }^{2}$ Department of Physiology, China Medical University, Taichung, Taiwan, R.O.C.; \\ ${ }^{3}$ Graduate Institute of Biomedical Sciences, China Medical University, Taichung, Taiwan, R.O.C.; \\ ${ }^{4}$ Terry Fox Cancer Research Laboratory, Department of Medical Research, \\ China Medical University Hospital, Taichung, Taiwan, R.O.C.; \\ ${ }^{5}$ Natiosnal Defense Medical Center, Taipei, Taiwan, R.O.C.; \\ ${ }^{6}$ Department of Bioinformatics and Medical Engineering, Asia University, Taichung, Taiwan, R.O.C.
}

\begin{abstract}
Background/Aim: Metalloproteinases (MMPs) are a family of proteases which have been shown to be overexpressed in various types of cancers. However, the contribution of MMP1 genotype to hepatocellular carcinoma (HCC) has not been well studied. This study aimed to evaluate the contribution of MMP1 promoter 1607 genotype to the risk of HCC in Taiwan, where HCC incidence is relatively high in the world. Materials and Methods: In this case-control study, MMP1 genotype and its interaction with consumption of cigarettes and alcohol in determining HCC risk was investigated among 298 HCC patients and 889 ageand gender-matched healthy controls. Results: The percentages of ever smokers and ever alcohol drinkers were much higher in the case group than in the control group. The percentages of $2 G / 2 G, 1 G / 2 G$ and $1 G / 1 G$ for $M M P 1$ promoter 1607 genotype were $37.2 \%, 38.3 \%$ and $24.5 \%$ in the HCC group and $34.8 \%, 44.0 \%$ and $21.2 \%$ in the control group, respectively ( $p$ for trend=0.2048). The allelic frequency distribution analysis showed the variant $1 G$ allele of MMPI promoter 1607 conferred similar HCC susceptibility as the wild-type $2 G$ allele (odds ratio
\end{abstract}

This article is freely accessible online.

*These Authors contributed equally to this study.

Correspondence to: Da-Tian Bau and Shou-Cheng Wang, Terry Fox Cancer Research Laboratory, China Medical University Hospital, 2 Yuh-Der Road, Taichung, 404 Taiwan, R.O.C. Tel: +886 422052121 Ext.7534, e-mail: datian@mail.cmuh.org.tw; artbau2@gmail.com

Key Words: Genotyping, hepatocellular carcinoma, MMP1, polymorphism.
$(O R)=1.01,95 \%$ confidence interval $(C I)=0.84-1.22$, $p=0.8735)$. As for the gene-lifestyle interaction, there was an obvious protective effect of MMP1 promoter $16071 G$ allele on the risk of HCC among non-smokers, but not nonsmokers, even alcohol drinkers or non-drinkers. Conclusion: The $1 G$ allele of MMP1 promoter 1607 may have a protective effect on HCC risk for non-smokers in Taiwan and further validations are needed in other population groups.

Statistically, hepatocellular carcinoma (HCC) is diagnosed in more than 500,000 people worldwide annually and is one of the leading causes of cancer-related deaths (1). Geographically, HCC incidence is of relatively high density in Taiwan, China and other Asia-Pacific regions but has a low incidence in the United States and Europe (2), and has been reported to be closely associated with chronic infection with hepatitis B (HBV) or C virus (HCV), aflatoxin exposure, cigarette smoking, alcohol consumption, cirrhosis, male gender and family history of $\operatorname{HCC}(3,4)$. In addition to these environmental factors, the genetic factors may contribute to the initiation and progression of HCC. In Taiwan, although specific biomarkers for HCC have been reported in recent years (5-9), the genomic susceptibility of HCC and the interactions among the genetic and environmental risk factors are largely unrevealed.

Extracellular matrix (ECM) components, which are composed of glycosaminoglycans and fibrous proteins, may contribute to the regulation and progression of morphogenesis, angiogenesis, inflammation, would healing and tumorigenesis (10). The matrix metalloproteinases (MMPs), also known as matrixins, are a family of calcium-dependent endopeptidases that play a key role in cell recruitment, migration (adhesion and dispersion), differentiation, angiogenesis, cell death 
Table I. Summary of selected characteristic data of the 298 patients with hepatocellular carcinoma and the 889 matched healthy controls.

\begin{tabular}{|c|c|c|c|c|c|c|c|}
\hline \multirow[t]{2}{*}{ Characteristic } & \multicolumn{3}{|c|}{ Controls $(\mathrm{n}=889)$} & \multicolumn{3}{|c|}{ Cases $(n=298)$} & \multirow[t]{2}{*}{$p$-Value } \\
\hline & $\mathrm{n}$ & $\%$ & Mean (SD) & $\mathrm{n}$ & $\%$ & Mean (SD) & \\
\hline Age (years) & & & $55.4(4.9)$ & & & $52.3(4.5)$ & 0.7418 \\
\hline \multicolumn{8}{|l|}{ Gender } \\
\hline Male & 636 & $71.5 \%$ & & 213 & $71.5 \%$ & & 0.9830 \\
\hline Female & 253 & $28.5 \%$ & & 85 & $28.5 \%$ & & \\
\hline \multicolumn{8}{|l|}{ Personal habits } \\
\hline Ever smokers & 579 & $65.1 \%$ & & 224 & $75.2 \%$ & & $0.0017 *$ \\
\hline Ever drinkers & 518 & $41.7 \%$ & & 206 & $69.1 \%$ & & $0.0011 *$ \\
\hline
\end{tabular}

SD: Standard deviation; aabased on Student's $t$-test and Chi-square test. *Statistically significant, $p<0.05$.

(apoptosis and autophagy), and control degradation of the components of connective tissue matrices (10-14). Homeostasis statuses of MMPs is under the control of a complex network (15), and the imbalance of MMPs, include MMP-1, was a common feature for HCC etiology (16-19). MMP1, also known as collagenase-1, is the most abundant MMP in ECM and under the control of activator protein-1 (AP1) that binds to the promoter region of mitogen-activated kinase through polyomavirus-enhancing activity-3 $(20,21)$. A polymorphic site was found in the $M M P 1$ promoter region at upstream position of $1607 \mathrm{bp}$, which was reported to control the transcriptional activity of the $M M P 1$ gene and was also correlated with the incidence and progression of several cancer types (22).

The genomic contribution of $M M P 1$ to cancer has not been well elucidated and few scientific reports have investigated its role in HCC. In 2005, Okamoto and his colleagues reported that the $2 \mathrm{G}$ allele of $M M P 1$ promoter 1607 polymorphism was not associated with risk of $\mathrm{HCC}$, compared with the $1 \mathrm{G}$ allele in a Japanese population with only $92 \mathrm{HCC}$ cases and 83 controls (16). In 2010, the same group further proposed that $I L-1 \beta-31 \mathrm{~T}$ allele and $M M P-3$ $5 \mathrm{~A}$ allele, but not $M M P-1$ allele, are cooperative risk factors for poor prognosis in HCC patients (23). Zhai and colleagues reported that $M M P 1$ promoter 1607 polymorphism was not associated with risk of HCC in 434 cases and 480 controls in south China (24). In the current study, we aimed to firstly reveal the contribution of $M M P 1$ genotype at the promoter 1607 site to the risk of HCC in Taiwanese.

\section{Materials and Methods}

Investigated population. Two hundred and ninety-eight patients diagnosed with HCC by Dr. Jeng were recruited at the Department of General Surgery at the China Medical University Hospital, Taiwan, in 2004-2010. Each patient and non-cancerous healthy person completed a self-administered questionnaire and provided their peripheral blood samples. Originally, three times as many noncancer healthy volunteers as controls were selected by matching for age and gender after initial random sampling from the Health Examination Cohort of our hospital. The exclusion criteria of the controls included previous malignancy, metastasized cancer from other or unknown origin, and any genetic or familial diseases. The included control population was 898 . Our study was approved by the Institutional Review Board of the China Medical University Hospital (DMR103-IRB-094), and written informed consent was obtained from all participants. The selected characteristic information extracted from personal questionales is summarized in Table I.

Genotyping conditions. The genomic DNA from the peripheral blood leucocytes of each investigated subject was prepared applying the QIAamp Blood Mini Kit (Blossom, Taipei, Taiwan) and stored at $-80^{\circ} \mathrm{C}$ until processed as per our recent publications (25-28). The sequences of primers and the restriction enzymes for MMP1 promoter 1607 genotyping are the same as our previous publication (29-31). Briefly, the sequences for forward and reverse primer pairs were 5'-TGACTTTTAAAACATAGTCTATGT-3' and 5'-GATTG ATTTGAGATAAGTCATAGC-3', respectively. The polymerase chain reaction (PCR) cycling conditions were set as: one cycle at $94^{\circ} \mathrm{C}$ for $5 \mathrm{~min} ; 35$ cycles of $94^{\circ} \mathrm{C}$ for $30 \mathrm{~s}, 58^{\circ} \mathrm{C}$ for $30 \mathrm{~s}$, and $72^{\circ} \mathrm{C}$ for $30 \mathrm{~s}$; and a final extension step at $72^{\circ} \mathrm{C}$ for $10 \mathrm{~min}$. After PCR amplification, the PCR products were subject to the digestion by $A l u \mathrm{I}$ restriction endonuclease for $2 \mathrm{~h}$ at $37^{\circ} \mathrm{C}$ and separation via $3 \%$ agarose gel electrophoresis for $25 \mathrm{~min}$. The genotypes were identified as homozygous $2 \mathrm{G} / 2 \mathrm{G}$ with 269 -bp product, heterozygous $1 \mathrm{G} / 2 \mathrm{G}$ with 269-, 241- and 28-bp products, and homozygous $1 \mathrm{G} / 1 \mathrm{G}$ with 241- and 28-bp products, respectively. All the genotypic processing was repeated by two researchers independently and blindly, and all the genotyping results were $100 \%$ concordant.

Statistical analyses. Student's $t$-test was applied for the comparison of ages between the HCC case and the control groups. Pearson's Chi-square test was applied to compare the distribution of the MMP1 promoter 1607 genotypes among the subgroups. The associations between the $M M P 1$ promoter 1607 genotypes and HCC risk were estimated by computing odds ratios (ORs) and their $95 \%$ confidence intervals (CIs) from logistic regression analysis. Statistically, any difference at $p<0.05$ was taken as significant between the two groups compared. 
Table II. Distribution of matrix metalloproteinase-1 (MMP1) promoter 1607 genotypes among the 298 patients with hepatocellular carcinoma and the 889 matched healthy controls.

\begin{tabular}{|c|c|c|c|c|c|c|}
\hline & \multicolumn{2}{|c|}{ Controls } & \multicolumn{2}{|c|}{ Patients } & \multirow[t]{2}{*}{ OR $(95 \% \mathrm{CI})$} & \multirow[t]{2}{*}{$p$-Value ${ }^{\mathrm{a}}$} \\
\hline & $\mathrm{n}$ & $\%$ & $\mathrm{n}$ & $\%$ & & \\
\hline \multicolumn{7}{|l|}{ Genotype } \\
\hline $2 \mathrm{G} / 2 \mathrm{G}$ & 309 & $34.8 \%$ & 111 & $37.2 \%$ & 1.00 (Reference) & \\
\hline $1 \mathrm{G} / 2 \mathrm{G}$ & 391 & $44.0 \%$ & 114 & $38.3 \%$ & $0.82(0.60-1.10)$ & 0.1737 \\
\hline $1 \mathrm{G} / 1 \mathrm{G}$ & 189 & $21.2 \%$ & 73 & $24.5 \%$ & $1.08(0.76-1.52)$ & 0.6815 \\
\hline$P_{\text {trend }}$ & & & & & & 0.2048 \\
\hline \multicolumn{7}{|l|}{ Carrier comparison } \\
\hline $2 \mathrm{G} / 2 \mathrm{G}+1 \mathrm{G} / 2 \mathrm{G}$ & 700 & $78.8 \%$ & 225 & $75.5 \%$ & 1.00 (Reference) & \\
\hline $1 \mathrm{G} / 1 \mathrm{G}$ & 189 & $21.2 \%$ & 73 & $24.5 \%$ & $1.20(0.88-1.64)$ & 0.2436 \\
\hline $2 \mathrm{G} / 2 \mathrm{G}$ & 309 & $34.8 \%$ & 111 & $37.2 \%$ & 1.00 (Reference) & \\
\hline $1 \mathrm{G} / 1 \mathrm{G}+1 \mathrm{G} / 2 \mathrm{G}$ & 580 & $65.2 \%$ & 187 & $62.8 \%$ & $0.90(0.68-1.18)$ & 0.4366 \\
\hline
\end{tabular}

aBased on Chi-square test without Yate's correction.

Table III. Distribution of allelic frequencies for matrix metalloproteinase-1 (MMP1) promoter 1607 among the 298 patients with hepatocellular carcinoma and the 889 matched healthy controls.

\begin{tabular}{ccccccc}
\hline & Controls, $\mathrm{n}$ & $\%$ & Patients, $\mathrm{n}$ & $\%$ & OR $(95 \% \mathrm{CI})$ & $p$-Value \\
\hline Allele & & & & & & \\
2G & 1009 & $56.8 \%$ & 769 & $56.4 \%$ & 1.00 (Reference) \\
1G & 336 & $43.2 \%$ & 260 & $43.6 \%$ & $1.01(0.84-1.22)$ & 0.8735 \\
\hline
\end{tabular}

aBased on Chi-square test without Yate's correction.

\section{Results}

The frequency distributions of selected characters including age, gender and personal lifestyles for the $298 \mathrm{HCC}$ patients in the case group and 889 non-cancer healthy subjects in the control group are summarized and compared in Table I. Since we applied frequency matching to recruit the noncancer healthy subjects as the controls, it is granted that there was no difference in the distributions of age and gender between the control and case groups (Table I). For these investigated individuals, it was found that the percentages of ever smokers and ever alcohol drinkers were much higher in the case group than in the control one (Table I). These findings fit the previous reports that smoking and alcohol drinking are risk factors for HCC in Taiwan.

The distributions of the MMP1 promoter 1607 genotype among the 889 non-cancer controls and the 298 HCC patients are presented and statistically analyzed in Table II. The results showed that the genotypes of MMP1 promoter 1607 were not differently distributed between case and control groups ( $p$ for trend=0.2048) (Table II). In detail, the $M M P 1$ promoter 1607 heterozygous $1 \mathrm{G} / 2 \mathrm{G}$ and homozygous $1 \mathrm{G} / 1 \mathrm{G}$ were not associated with $\mathrm{HCC}$ risk, compared to wild-type $2 \mathrm{G} / 2 \mathrm{G}$ genotype $(\mathrm{OR}=0.82$ and $1.08,95 \% \mathrm{CI}=0.60-1.10$ and $0.76-$ $1.52, p=0.1737$ and 0.6815 , respectively; Table II). In the recessive and dominant models, there was still no association between the genotype of $M M P 1$ promoter 1607 and HCC risk $(\mathrm{OR}=1.20$ and $0.90,95 \% \mathrm{CI}=0.88-1.64$ and $0.68-1.18$, $p=0.2436$ and 0.4366 , respectively; Table II).

To confirm the results in Table II, the analysis of allelic frequency distribution for the MMPI promoter 1607 polymorphism was further conducted and the results are presented in Table III. Supporting the findings that neither heterozygous $1 \mathrm{G} / 2 \mathrm{G}$ nor homozygous $1 \mathrm{G} / 1 \mathrm{G}$ genotype of MMP1 promoter 1607 was associated with HCC risk, the variant allele $1 \mathrm{G}$ was found at $43.6 \%$ in the case group, nonsignificantly different from that of $43.2 \%$ in the control group $(\mathrm{OR}=1.01,95 \% \mathrm{CI}=0.84-1.22, p=0.8735)$. To sum-up, there was no significant difference in the allelic frequencies of MMPl promoter 1607 between the case and control groups (Table III).

Since we found that smoking and alcohol drinking are risk factors for HCC in Taiwan, we were interested in investigating the interactions between the genotype of MMP1 
Table IV. Odds ratios for matrix metalloproteinase-1 (MMP1) promoter 1607 genotype and hepatocellular carcinoma after stratification by smoking status.

\begin{tabular}{|c|c|c|c|c|c|c|c|c|c|c|}
\hline \multirow[t]{2}{*}{ Genotype } & \multicolumn{2}{|c|}{ Non-smokers, $\mathrm{n}$} & \multirow{2}{*}{$\begin{array}{c}\text { OR } \\
(95 \% \mathrm{CI})^{\mathrm{a}}\end{array}$} & \multirow{2}{*}{$\begin{array}{c}\mathrm{aOR} \\
(95 \% \mathrm{CI})^{\mathrm{b}}\end{array}$} & \multirow[t]{2}{*}{$p$-Value } & \multicolumn{2}{|c|}{ Smokers, $\mathrm{n}$} & \multirow{2}{*}{$\begin{array}{c}\text { OR } \\
(95 \% \mathrm{CI})^{\mathrm{a}}\end{array}$} & \multirow{2}{*}{$\begin{array}{c}\mathrm{aOR} \\
(95 \% \mathrm{CI})^{\mathrm{b}}\end{array}$} & \multirow[t]{2}{*}{$p$-Value } \\
\hline & Controls & Cases & & & & Controls & Cases & & & \\
\hline $2 \mathrm{G} / 2 \mathrm{G}$ & 100 & 36 & 1.00 (ref) & 1.00 (ref) & & 209 & 75 & 1.00 (ref) & 1.00 (ref) & \\
\hline $1 \mathrm{G} / 2 \mathrm{G}$ & 139 & 26 & $0.52(0.30-0.92)$ & $0.54(0.33-0.90)$ & $0.0222 *$ & 252 & 88 & $0.97(0.68-1.39)$ & $0.99(0.71-1.33)$ & 0.8816 \\
\hline $1 \mathrm{G} / 1 \mathrm{G}$ & 71 & 12 & $0.47(0.23-0.97)$ & $0.44(0.25-0.95)$ & $0.0371 *$ & 118 & 61 & $1.44(0.96-2.16)$ & $1.41(0.94-2.11)$ & 0.0777 \\
\hline Total & 310 & 74 & & & & 579 & 224 & & & \\
\hline
\end{tabular}

aBy multivariate logistic regression analysis. ${ }^{b}$ By multivariate logistic regression analysis after adjusting of age, gender and alcohol drinking status; *Statistically significant.

Table V. Odds ratios for matrix metalloproteinase-1 (MMP1) promoter 1607 genotype and hepatocellular carcinoma after stratification by alcohol drinking status.

\begin{tabular}{|c|c|c|c|c|c|c|c|c|c|c|}
\hline \multirow[t]{2}{*}{ Genotype } & \multicolumn{2}{|c|}{ Non-drinker, $\mathrm{n}$} & \multirow{2}{*}{$\begin{array}{c}\text { OR } \\
(95 \% \mathrm{CI})^{\mathrm{a}}\end{array}$} & \multirow{2}{*}{$\begin{array}{c}\mathrm{aOR} \\
(95 \% \mathrm{CI})^{\mathrm{b}}\end{array}$} & \multirow[t]{2}{*}{$p$-Value } & \multicolumn{2}{|c|}{ Drinkers, $\mathrm{n}$} & \multirow{2}{*}{$\begin{array}{c}\text { OR } \\
(95 \% \mathrm{CI})^{\mathrm{a}}\end{array}$} & \multirow{2}{*}{$\begin{array}{c}\mathrm{aOR} \\
(95 \% \mathrm{CI})^{\mathrm{b}}\end{array}$} & \multirow[t]{2}{*}{$p$-Value } \\
\hline & Controls & Cases & & & & Controls & Cases & & & \\
\hline $2 \mathrm{G} / 2 \mathrm{G}$ & 127 & 36 & $1.00(\mathrm{ref})$ & $1.00(\mathrm{ref})$ & & 182 & 75 & 1.00 (ref) & $1.00(\mathrm{ref})$ & \\
\hline $1 \mathrm{G} / 2 \mathrm{G}$ & 163 & 37 & $0.80(0.48-1.34)$ & $0.82(0.49-1.29)$ & 0.3965 & 228 & 77 & $0.82(0.56-1.19)$ & $0.79(0.57-1.21)$ & 0.2952 \\
\hline $1 \mathrm{G} / 1 \mathrm{G}$ & 81 & 19 & $0.83(0.44-1.54)$ & $0.84(0.45-1.58)$ & 0.5503 & 108 & 54 & $1.21(0.79-1.85)$ & $1.16(0.82-1.93)$ & 0.3701 \\
\hline Total & 371 & 92 & & & & 518 & 206 & & & \\
\hline
\end{tabular}

${ }^{a}$ By multivariate logistic regression analysis. ${ }^{b}$ By multivariate logistic regression analysis after adjusting of age, gender and smoking status; *Statistically significant.

promoter 1607 and personal cigarette smoking and alcohol drinking habits. Among the non-smokers, those with genotype of $1 \mathrm{G} / 2 \mathrm{G}$ or $1 \mathrm{G} / 1 \mathrm{G}$ at $M M P 1$ promoter 1607 were at 0.52 - and 0.47 -fold odds of having $\mathrm{HCC}(95 \% \mathrm{CI}=0.30$ 0.92 and $0.23-0.97, p=0.0222$ and 0.0371 , respectively), seemingly conferring a protective effect, but this was not the case among those smokers (Table IV). After the adjusting of age, gender and alcohol drinking status, the significance were still existing at the similar level $(\mathrm{OR}=0.54$ and 0.44 , 95\% CI=0.33-0.90 and 0.25-0.95, respectively, Table IV). There was no such close interaction of MMP1 promoter 1607 genotype with personal alcohol drinking habits (Table V).

\section{Discussion}

In the literature, MMP-1, together with MMP-2, $-9,-13$ and their regulators TIMP-1 and -2 are involved in the liver fibrosis processions (32-36), but few has studied the genomic contribution of $M M P-1$ to the carcinogenesis of HCC. In the current hospital-based case-control study, the contribution of $M M P 1$ promoter 1607 to $\mathrm{HCC}$ risk and its interaction with alcohol drinking and cigarette smoking were firstly examined among Taiwanese. The results showed that although neither the genotypic (Table II) nor the allelic frequencies (Table III) of $M M P 1$ promoter 1607 were differentially distributed among the HCC patients and non-cancer healthy controls, the $1 \mathrm{G}$ allele was a protective determinant for risk of $\mathrm{HCC}$ among the non-smokers (Table IV).

This is the first study to reveal an interaction between MMP1 1607 genotype and cigarette smoking on the susceptibility to HCC. Previously, long-term tobacco smoking has been shown to contribute to the etiology of $\mathrm{HCC}$ development (37-40) but little was known about the contributions of genomic factors to HCC development. Recently, others and our team have reported that specific genotypes may be combined with cigarette smoking habits and contribute to increased HCC risk, such as the polymorphisms on CYPIAI (41), N-acetyltransferase 2 (42) and tumor necrosis factor-alpha (9). Several genomic markers did not have joint effects with cigarette smoking habit on HCC risk $(5,8)$. However, the overall mechanisms are very complex and need more investigations. In Table I, it can be found that a higher proportion of individuals had consumed cigarettes and alcohol in the group of patients with HCC than the controls. However, the incomplete records of other factors, such as infection status with hepatitis B (HBV) or C virus (HCV), limited us to observe the interactions of genotypes of $M M P 1$ 1607 with these environmental factors of HCC in Taiwan. 
MMP1 has been reported to be in charge of the degradation of the interstitial collagens, hence it is called collagenase-1. In normal conditions, MMP1 is under the suppression of TIMP1 $(43,44)$ and elevated MMP1 has been reported to play an important role in invasive and migration capacity of tumor cells (45). Mounting evidence indicates that elevated MMP1 expression was observed in the borders of solid tumors, such as breast and oral cancer (46-48). Mechanically, MMP1 is thought to promote invasion and metastasis through the degradation of the ECM as the main component of connective tissue, like to relieve the reins for the horses (49-51). In 2012, Liu and his colleagues performed a meta-analysis exploring the association between $M M P 1$ promoter $16071 \mathrm{G} / 2 \mathrm{G}$ polymorphism and risk of several types of cancer, and the results showed that an elevated cancer risk was found regarding breast, colorectal, genitourinary neoplasm but not HCC (52). The dynamic balance between MMPs and TIMPs play a pivotal role in the maintenance of normal physiological conditions for cells, but it seems that the closely regulation of MMP1 by TIMP1 in HCC tissues is not as simple as a 'see-saw' relationship. In 2009, Altadill and his colleagues reported that overexpressed MMP-1 by fibroblast cells is correlated with poor prognosis (19), supported by the findings that overexpressed MMP-1 was associated with an elevated metastasis capacity of the HCC cells $(53,54)$. Altadill and his colleagues also reported that overexpressed TIMP1 by stromal cells is correlated with shortened overall survival period (19), and accordingly TIMP-1 overexpression was reported to be associated increased invasive and metastatic capacity of the HCC cells $(55,56)$. In the near future, further analysis of TIMPI genotype/phenotype may provide further evidence for evaluating the contribution of combined genotypes of $M M P$ 1 and TIMPI to the carcinogenesis of HCC. In addition, the promoter assay with the different genotypes of $M M P-11607$ and possible TIMPl promoter polymorphic site, may add more evidence for the functional differences between the different genotypes or haplotypes. Moreover, the involvement of smoking in etiology of HCC, especially the initial step of unbalanced DNA damage, was accessible with the treatment of cigarette components to the cells with different $M M P-1$ and/or TIMP1 genotypes. Of course, the geneticenvironmental interactions could also be approached with the treatments of increasing doses of cigarette components to the cells with different $M M P-1$ and/or TIMP1 genotypes, and investigating their genomic instability. It is very possibly that the cells with $2 \mathrm{G} / 2 \mathrm{G}$ genotypes at $M M P-11607$ with highest dose of BPDE, an ultimate carcinogenic metabolite of tobacco smoke carcinogen benzo[a]pyrene, was of the highest instable genomic integrity, which is mostly prone to carcinogenesis.

In conclusion, the study provides evidence that the $1 \mathrm{G}$ allele at MMP1 promoter 1607 may interact with personal smoking status to determine the personal susceptibility to HCC, and more investigations should be conducted to reveal the detail alteration of ECM components with HCC risk and prognosis.

\section{Acknowledgements}

The Authors declare no conflict of interest in regard to this study. We appreciate the Tissue-bank of China Medical University Hospital for their excellent technical assistance. This study was supported mainly by the grant 105A11 of Taichung Armed Forces General Hospital to Dr. Lai and partially by research grant from Taiwan Ministry of Health and Welfare Clinical Trial and Research Center of Excellence (MOHW105-TDU-B-212-133019).

\section{References}

1 Torre LA, Bray F, Siegel RL, Ferlay J, Lortet-Tieulent J and Jemal A: Global cancer statistics, 2012. CA Cancer J Clin 65: 87-108, 2015

2 Yang JD and Roberts LR: Hepatocellular carcinoma: a global view. Nat Rev Gastroenterol Hepatol 7: 448-458, 2010.

3 Beasley RP: Hepatitis B virus. The major etiology of hepatocellular carcinoma. Cancer 61: 1942-1956, 1988.

$4 \mathrm{Yu}$ MW and Chen CJ: Hepatitis B and C viruses in the development of hepatocellular carcinoma. Crit Rev Oncol Hematol 17: 71-91, 1994.

5 Chang WS, Yang MD, Tsai CW, Cheng LH, Jeng LB, Lo WC, Lin CH, Huang CY and Bau DT: Association of cyclooxygenase 2 single-nucleotide polymorphisms and hepatocellular carcinoma in Taiwan. Chin J Physiol 55: 1-7, 2012.

6 Hsu CM, Yang MD, Chang WS, Jeng LB, Lee MH, Lu MC, Chang SC, Tsai CW, Tsai Y, Tsai FJ and Bau DT: The contribution of XRCC6/Ku70 to hepatocellular carcinoma in Taiwan. Anticancer Res 33: 529-535, 2013.

7 Hsu CM, Yang MD, Tsai CW, Ho CY, Chang WS, Chang SC, Jeng LB, Tsai Y, Tsai FJ and Bau DT: The contribution of caveolin-1 genotype and phenotype to hepatocellular carcinoma. Anticancer Res 33: 671-677, 2013.

8 Hsieh YH, Chang WS, Tsai CW, Tsai JP, Hsu CM, Jeng LB and Bau DT: DNA double-strand break repair gene XRCC7 genotypes were associated with hepatocellular carcinoma risk in Taiwanese males and alcohol drinkers. Tumour Biol 36: 4101-4106, 2015.

9 Yang MD, Hsu CM, Chang WS, Yueh TC, Lai YL, Chuang CL, Wang SC, Jeng LB, Ji HX, Hsiao CL, Wu CN, Tsai CW, Chung JG and Bau DT: Tumor necrosis factor-alpha genotypes are associated with hepatocellular carcinoma risk in Taiwanese males, smokers and alcohol drinkers. Anticancer Res 35: 54175423, 2015.

10 Woessner JF Jr.: Matrix metalloproteinases and their inhibitors in connective tissue remodeling. Faseb J 5: 2145-2154, 1991.

11 Mannello F, Luchetti F, Falcieri E and Papa S: Multiple roles of matrix metalloproteinases during apoptosis. Apoptosis 10: 1924, 2005 .

12 Augustin S, Berard M, Kellaf S, Peyri N, Fauvel-Lafeve F, Legrand $\mathrm{C}, \mathrm{He} \mathrm{L}$ and Crepin M: Matrix metalloproteinases are involved in both type I (apoptosis) and type II (autophagy) cell death induced by sodium phenylacetate in MDA-MB-231 breast tumour cells. Anticancer Res 29: 1335-1343, 2009. 
13 Mannello F: Multipotent mesenchymal stromal cell recruitment migration, and differentiation: what have matrix metalloproteinases got to do with it? Stem Cells 24: 1904-1907, 2006.

14 Rundhaug JE: Matrix metalloproteinases and angiogenesis. J Cell Mol Med 9: 267-285, 2005.

15 Murphy G and Docherty AJ: The matrix metalloproteinases and their inhibitors. Am J Respir Cell Mol Biol 7: 120-125, 1992.

16 Okamoto K, Mandai M, Mimura K, Murawaki Y and Yuasa I: The association of MMP-1, -3 and -9 genotypes with the prognosis of HCV-related hepatocellular carcinoma patients. Res Commun Mol Pathol Pharmacol 117-118: 77-89, 2005.

17 Sakamoto Y, Mafune K, Mori M, Shiraishi T, Imamura H, Mori M, Takayama T and Makuuchi M: Overexpression of MMP-9 correlates with growth of small hepatocellular carcinoma. Int J Oncol 17: 237-243, 2000.

$18 \mathrm{Kim}$ JH, Kim TH, Jang JW, Jang YJ, Lee KH and Lee ST: Analysis of matrix metalloproteinase mRNAs expressed in hepatocellular carcinoma cell lines. Mol Cells 12: 32-40, 2001.

19 Altadill A, Rodriguez M, Gonzalez LO, Junquera S, Corte MD, Gonzalez-Dieguez ML, Linares A, Barbon E, Fresno-Forcelledo M, Rodrigo L and Vizoso FJ: Liver expression of matrix metalloproteases and their inhibitors in hepatocellular carcinoma. Dig Liver Dis 41: 740-748, 2009.

20 Sharrocks AD, Brown AL, Ling Y and Yates PR: The ETSdomain transcription factor family. Int J Biochem Cell Biol 29 : 1371-1387, 1997.

21 Westermarck J, Seth A and Kahari VM: Differential regulation of interstitial collagenase (MMP-1) gene expression by ETS transcription factors. Oncogene 14: 2651-2660, 1997.

22 Rutter JL, Mitchell TI, Buttice G, Meyers J, Gusella JF, Ozelius LJ and Brinckerhoff CE: A single nucleotide polymorphism in the matrix metalloproteinase-1 promoter creates an Ets binding site and augments transcription. Cancer Res 58: 5321-5325, 1998.

23 Okamoto K, Ishida C, Ikebuchi Y, Mandai M, Mimura K, Murawaki Y and Yuasa I: The genotypes of IL-1 beta and MMP3 are associated with the prognosis of $\mathrm{HCV}$-related hepatocellular carcinoma. Intern Med 49: 887-895, 2010.

24 Zhai Y, Qiu W, Dong XJ, Zhang XM, Xie WM, Zhang HX, Yuan XY, Zhou GQ and He FC: Functional polymorphisms in the promoters of MMP-1, MMP-2, MMP-3, MMP-9, MMP-12 and MMP-13 are not associated with hepatocellular carcinoma risk. Gut 56: 445-447, 2007.

25 Chang WS, Liao CH, Tsai CW, Hu PS, Wu HC, Hsu SW, Hsiao $\mathrm{CL}$, Hsu CH, Hung YW and Bau DT: Association of enhancer of Zeste 2 (EZH2) genotypes with bladder cancer risk in Taiwan. Anticancer Res 36: 4509-4514, 2016.

26 Chang WS, Liao CH, Tsai CW, Hu PS, Wu HC, Hsu SW, Ji HX, Hsiao CL and Bau DT: The Role of IL-10 promoter polymorphisms in renal cell carcinoma. Anticancer Res 36: 2205-2209, 2016.

27 Chang WS, Yueh TC, Tsai CW, Ji HX, Wu CN, Wang SC, Lai YL, Hsu SW, Hsieh MH, Hsiao CL, Hung YW, Shih TC and Bau DT: Contribution of DNA repair xeroderma pigmentosum group D genotypes to colorectal cancer risk in Taiwan. Anticancer Res 36: 1657-1663, 2016.

28 Pei JS, Chang WS, Hsu PC, Tsai CW, Hsu CM, Ji HX, Hsiao CL, Hsu YN and Bau DT: The Association of Flap Endonuclease 1 Genotypes with the Risk of Childhood Leukemia. Cancer Genomics Proteomics 13: 69-74, 2016.
29 Pei JS, Hsu PC, Chou AK, Tsai CW, Chang WS, Hsiao CL, Hsu YN, Cheng SP and Bau DT: Matrix metalloproteinase-1 genotype contributes to the risk of non-solid tumor in childhood leukemia. Anticancer Res 36: 5127-5132, 2016.

$30 \mathrm{Su}$ CH, Lane HY, Hsiao CL, Liu LC, Ji HX, Li HT, Yen ST, Su $\mathrm{CH}$, Hsia TC, Chang WS, Tsai CW and Bau DT: Matrix metalloproteinase-1 genetic polymorphism in breast cancer in Taiwanese. Anticancer Res 36: 3341-3345, 2016.

31 Tsai CW, Chang WS, Gong CL, Shih LC, Chen LY, Lin EY, Li HT, Yen ST, Wu CN and Bau DT: Contribution of matrix metallopeptidase-1 genotypes, smoking, alcohol drinking and areca chewing to nasopharyngeal carcinoma susceptibility. Anticancer Res 36: 3335-3340, 2016.

32 Sawada S, Murakami K, Murata J, Tsukada K and Saiki I: Accumulation of extracellular matrix in the liver induces high metastatic potential of hepatocellular carcinoma to the lung. Int J Oncol 19: 65-70, 2001.

33 Milani S, Herbst H, Schuppan D, Grappone C, Pellegrini G, Pinzani M, Casini A, Calabro A, Ciancio G, Stefanini F et al: Differential expression of matrix-metalloproteinase-1 and -2 genes in normal and fibrotic human liver. Am J Pathol 144: 528-537, 1994.

34 Benyon RC, Iredale JP, Goddard S, Winwood PJ and Arthur MJ: Expression of tissue inhibitor of metalloproteinases 1 and 2 is increased in fibrotic human liver. Gastroenterology 110: 821831, 1996.

35 Kapranos N, Karaiossifidi H, Kouri E and Vasilaros S: Nm23 expression in breast ductal carcinomas: a ten year follow-up study in a uniform group of node-negative breast cancer patients. Anticancer Res 16: 3987-3990, 1996.

36 Takahara T, Furui K, Yata Y, Jin B, Zhang LP, Nambu S, Sato $\mathrm{H}$, Seiki $M$ and Watanabe A: Dual expression of matrix metalloproteinase-2 and membrane-type 1-matrix metalloproteinase in fibrotic human livers. Hepatology 26: 1521-1529, 1997.

37 Austin H, Delzell E, Grufferman S, Levine R, Morrison AS, Stolley PD and Cole P: A case-control study of hepatocellular carcinoma and the hepatitis B virus, cigarette smoking, and alcohol consumption. Cancer Res 46: 962-966, 1986.

38 Yu MW, Chen CJ, Luo JC, Brandt-Rauf PW, Carney WP and Santella RM: Correlations of chronic hepatitis B virus infection and cigarette smoking with elevated expression of neu oncoprotein in the development of hepatocellular carcinoma. Cancer Res 54: 5106-5110, 1994.

39 Kuper H, Tzonou A, Kaklamani E, Hsieh CC, Lagiou P, Adami HO, Trichopoulos D and Stuver SO: Tobacco smoking, alcohol consumption and their interaction in the causation of hepatocellular carcinoma. Int J Cancer 85: 498-502, 2000.

40 Koh WP, Robien K, Wang R, Govindarajan S, Yuan JM and Yu MC: Smoking as an independent risk factor for hepatocellular carcinoma: the Singapore Chinese Health Study. Br J Cancer 105: 1430-1435, 2011.

41 Yu L, Sun L, Jiang YF, Lu BL, Sun DR and Zhu LY: Interactions between CYP1A1 polymorphisms and cigarette smoking are associated with the risk of hepatocellular carcinoma: evidence from epidemiological studies. Mol Biol Rep 39: 6641-6646, 2012.

42 Zhang J, Xu F and Ouyang C: Joint effect of polymorphism in the $\mathrm{N}$-acetyltransferase 2 gene and smoking on hepatocellular carcinoma. Tumour Biol 33: 1059-1063, 2012. 
43 Nagase H and Woessner JF Jr.: Matrix metalloproteinases. J Biol Chem 274: 21491-21494, 1999.

44 Surlin V, Ioana $M$ and Plesea IE: Genetic patterns of metalloproteinases and their tissular inhibitors - clinicopathologic and prognostic significance in colorectal cancer. Rom J Morphol Embryol 52: 231-236, 2011.

45 Kessenbrock K, Plaks V and Werb Z: Matrix metalloproteinases: regulators of the tumor microenvironment. Cell 141: 52-67, 2010.

46 Boire A, Covic L, Agarwal A, Jacques S, Sherifi S and Kuliopulos A: PAR1 is a matrix metalloprotease-1 receptor that promotes invasion and tumorigenesis of breast cancer cells. Cell 120: 303313, 2005.

47 George A, Ranganathan K and Rao UK: Expression of MMP-1 in histopathological different grades of oral squamous cell carcinoma and in normal buccal mucosa - an immunohistochemical study. Cancer Biomark 7: 275-283, 2010.

48 Zhou J, Brinckerhoff C, Lubert S, Yang K, Saini J, Hooke J, Mural R, Shriver C and Somiari S: Analysis of matrix metalloproteinase-1 gene polymorphisms and expression in benign and malignant breast tumors. Cancer Invest 29: 599-607, 2011.

49 Uhlmann ME, Georgieva M, Sill M, Linnemann U and Berger MR: Prognostic value of tumor progression-related gene expression in colorectal cancer patients. J Cancer Res Clin Oncol 138: 1631-1640, 2012.

50 Zhang M, Teng XD, Guo XX, Li ZG, Han JG and Yao L: Expression of tissue levels of matrix metalloproteinases and their inhibitors in breast cancer. Breast 22: 330-334, 2013.

51 Kurahara S, Shinohara M, Ikebe T, Nakamura S, Beppu M, Hiraki A, Takeuchi H and Shirasuna K: Expression of MMPS, MT-MMP, and TIMPs in squamous cell carcinoma of the oral cavity: correlations with tumor invasion and metastasis. Head Neck 21: 627-638, 1999.
52 Liu D, Guo H, Li Y, Xu X, Yang K and Bai Y: Association between polymorphisms in the promoter regions of matrix metalloproteinases (MMPs) and risk of cancer metastasis: a meta-analysis. PLoS One 7: e31251, 2012.

53 Kang Y, Siegel PM, Shu W, Drobnjak M, Kakonen SM, CordonCardo C, Guise TA and Massague J: A multigenic program mediating breast cancer metastasis to bone. Cancer Cell 3: 537549, 2003.

54 Przybylowska K, Kluczna A, Zadrozny M, Krawczyk T, Kulig A, Rykala J, Kolacinska A, Morawiec Z, Drzewoski J and Blasiak J: Polymorphisms of the promoter regions of matrix metalloproteinases genes MMP-1 and MMP-9 in breast cancer. Breast Cancer Res Treat 95: 65-72, 2006.

55 Roeb E, Bosserhoff AK, Hamacher S, Jansen B, Dahmen J, Wagner $S$ and Matern S: Enhanced migration of tissue inhibitor of metalloproteinase overexpressing hepatoma cells is attributed to gelatinases: relevance to intracellular signaling pathways. World J Gastroenterol 11: 1096-1104, 2005.

56 Nakatsukasa H, Ashida K, Higashi T, Ohguchi S, Tsuboi S, Hino N, Nouso K, Urabe Y, Kinugasa N, Yoshida K, Uematsu S, Ishizaki M, Kobayashi Y and Tsuji T: Cellular distribution of transcripts for tissue inhibitor of metalloproteinases 1 and 2 in human hepatocellular carcinomas. Hepatology 24: 82-88, 1996.
Received January 31, 2017

Revised February 28, 2017

Accepted February 28, 2017 